\title{
PENGARUH STATUS DESA WISATA TERHADAP KEHIDUPAN MASYARAKAT DESA PONGGOK
}

\author{
Asep Parantika ${ }^{1}$ \\ ${ }^{1)}$ Politeknik Sahid \\ e-mail: asepparantika@ polteksahid.ac.id
}

\begin{abstract}
Abstrak
Desa Ponggok adalah desa wisata yang terletak $40 \mathrm{~km}$ dari Yogyakarta, berada di Kecamatan Polanharjo. Desa ini termasuk BUMDES (Badan Usaha Manajemen Desa) terbaik ditingkat nasional serta mendapatkan penghargaan sebagai desa trendy. Desa yang awalnya di sebut sebagai desa termiskin sekarang telah bertransformasi menjadi desa yang berpendapatan tinggi berkat keberhasilan mengelola dana desa. Keberhasilan ini diperoleh dari pemanfaatan potensi wisata yang ada di desa tersebut salah satunya umbul ponggok, yaitu umbul yang paling menonjol diantara umbul umbul lain yang ada di desa ini. Penelitian ini bertujuan untuk mengetahui dampak sosial, ekonomi, dan budaya masyarakat desa ponggok terhadap status desa wisata. Metode yang dipakai dalam penelitian ini merupakan metode penelitian analisis deskriptif dengan pendekatan kualitatif. Menyandang status sebagai Desa Wisata membuat perubahan serta kemajuan dalam kehidupan masyarakat. Dampak yang dialami masyarakat desa diantaranya kehidupan masyarakat desa menjadi lebih modern, banyak masyarakat yang beralih profesi yang awalnya petani menjadi pekerja jasa wisata, hal ini membuat pendapatan masyarakat mengalami peningkatan, tingkat pendidikan dan tingkat kesejahteraan masyarakat juga ikut mengalami peningkatan. Pengelolaan objek wisata ini juga membuat masyarakat dapat meningkatkan keterampilan serta kreatifitas dalam hal membuka serta mengelola usaha yang telah mereka bangun.
\end{abstract}

Kata kunci : Budaya, Dampak, Desa Wisata, Ekonomi, Masyarakat, Sosial

\begin{abstract}
Ponggok Village is a tourist village located $40 \mathrm{~km}$ from Yogyakarta, located in Polanharjo District. This village is one of the best BUMDES (Village Management Enterprises) at the national level and received an award as a trendy village. The village which was originally called the poorest village has now been transformed into a high-income village thanks to the success of managing village funds. This success is obtained from the utilization of tourism potential in the village, one of which is the ponggok pennant, which is the most prominent pennant among other pennants in this village. This study aims to determine the social, economic, and cultural impacts of the people of Ponggok village on the status of tourism villages. The method used in this study is a descriptive analysis research method with a qualitative approach. Having the status as a Tourism Village makes changes and advances in people's lives. Impacts experienced by rural communities include the life of rural communities becoming more modern, many people who switched professions who were initially farmers to become tourism service workers, this has made community incomes have increased, education levels and levels of community welfare have also increased. The management of these attractions also allows people to improve their skills and creativity in opening and managing businesses they have built.
\end{abstract}

Keywords: Culture, Impact, Tourism Village, Economy, Society, Social

\section{PENDAHULUAN}

Negara Indonesia adalah negara kepulauan terbesar di dunia. Negara Indonesia berada diantara dua benua yaitu Benua Asia dan Benua Australia, diantara Samudera Pasifik dan Samudera Hindia, dimana Indonesia terdiri dari 17.504 pulau, dan memiliki populasi sebanyak 270.054.853 jiwa pada tahun 2018. Wilayah Indonesia yang begitu luas menjadikan negara ini kaya akan potensi sember daya alam dan potensi pariwisata. Keindahan bentang alam dan budaya 
yang beragam mampu menjadi potensi wilayah pariwisata. Dengan adanya wilayah pariwisata yang dimiliki Indonesia dapat menarik wisatawan untuk berkunjung. Dari tahun ke tahun jumlah wisatawan asing maupun domestik semakin mengalami peningkatan, hal itu menjadikan perolehan devisa negara Indonesia meningkat. Dengan kata lain pariwisata merupakan sektor yang berperan penting sebagai penggerak perekonomian di Indonesia.

Grafik 1

Pendapatan Devisa Indonesia dari Sektor Pariwisata Tahun 2009-2019

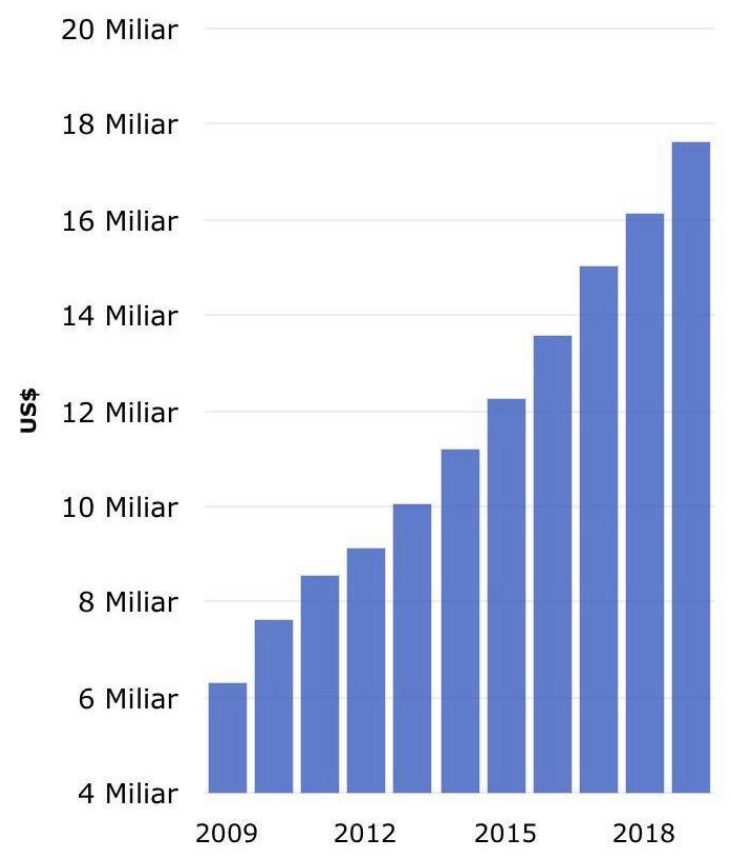

Sumber : Kementerian Kebudayaan dan Pariwisata, 2018

Berdasarkan data Kementrian Pariwisata tercatat pada tahun 2015 sektor pariwisata menempati urutan ke empat sebagai penyumbang devisa terbesar, setelah migas, batu bara, dan kelapa sawit. Pada tahun 2019 devisa sektor pariwisata ditargetkan dapat mengalahkan hasil ekspor sawit dan migas yaitu sebesar US\$ 20 miliar. Sedangkan tahun 2020 devisa sektor pariwisata ditargetkan bisa mencapai 21 juta dolar AS atau sekitar Rp 294 miliar oleh Menteri Pariwisata, Wishnutama. Negara Indonesia memiliki beraneka ragam suku dan budaya yang terbentang luas dari sabang sampai marauke, dimana masing- masing daerah memiliki potensi budaya yang dapat dikembangkan sebagai daya tarik pariwisata. Data BPS mencatat pada bulan Juli 2018 Indonesia memiliki 34 provinsi, 416 kabupaten, 98 kotamadya, 7.094 kecamatan, 8.480 kelurahan, dan 74.957 desa. Dari banyaknya desa yang ada di Indonesia terdapat 1.734 desa yang telah ditetapkan pemerintah sebagai desa wisata. Berdasarkan data tersebut, 1.734 desa wisata tersebar di masingmasing kepulauan yang ada di Indonesia. Dimana Pulau Jawa - Bali menempati urutan pertama sebagai pemilik desa wisata terbanyak yaitu 857 desa wisata, Sumatera pada urutan kedua yang memiliki 355 desa, Nusa Tenggara pada urutan keempat yang memiliki 189 desa, Sulawesi pada urutan ke lima yang memiliki sebanyak 119 desa, Kalimantan pada urutan keenam dengan 117 desa, Papua pada urutan ketujuh sebanyak 74 desa, dan yang terakhir Maluku pada urutan kedelapan dimana memiliki sebanyak 23 desa wisata.

Desa wisata adalah desa yang dikelola oleh komunitas atau masyarakat desa tersebut yang saling berinteraksi dalam melakukan pengelolaan terhadap kepedulian, memiliki kesadaran untuk berperan bersama sesuai keterampilan maupun kemampuan masing-masing individu dalam mengembangkan potensi yang dimiliki desa secara kondusif bagi tumbuh dan berkembangnya kepariwisataan yang ada di wilayahnya. Di Kelaten sendiri ada beberapa desa wisata yang sudah ditetapkan pemerintah, namun yang paling menonjol adalah Desa Wisata Ponggok. Desa Wisata 
Ponggok memiliki luas wilayah sekitar 77,2255 hektar dan jumlah penduduk 2.036 jiwa. Desa Wisata Ponggok terletak $40 \mathrm{~km}$ dari Yogyakarta, berada di Kecamatan Polanharjo. Desa ini termasuk BUMDES (Badan Usaha Manajemen Desa) terbaik ditingkat nasional serta mendapatkan penghargaan sebagai desa trendy. Pada tahun 2008 pendapatan desa sekitar 15 juta pertahun dan terus meningkat hingga 2015 mendapati 5,1 miliar dan melebihi target sekitar 3,8 miliar. Dalam setahun mampu menghasilkan 16 miliar. Karna keberhasilan masyarakat setempat dalam mengelola potensi yang ada di daerah tersebut, menjadikan desa wisata ini memiliki pendapatan yang cukup besar disetiap tahunnya.

\section{Gambar 2 \\ Jumlah Wisatawan Mancanegara dan Domestik di Provinsi Jawa Tengah, 2011-2018}

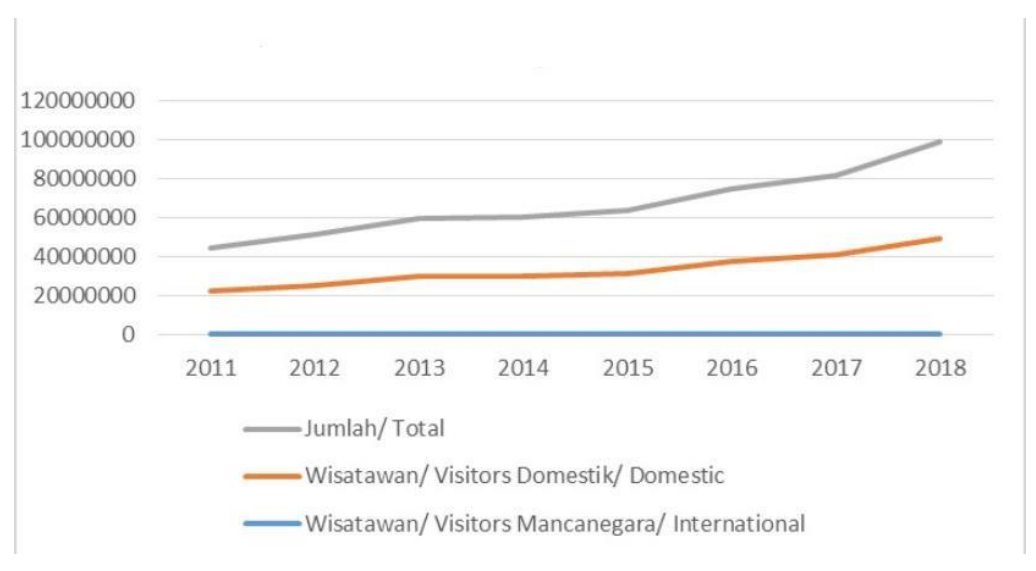

Sumber: Dinas Kebudayaan dan Pariwisata Provinsi Jawa Tengah, 2018

Dari grafik di atas dapat di ketahui bahwa jumlah kunjungan wisatawan mancanegara maupun domestik yang berwisata ke Provinsi Jawa Tengah pada tahun 2011-2018 mengalami peningkatan dan tidak menutup kemungkinan bahwa setengah dari pengunjung yang berkunjung ke Jawa Tengah berkunjung ke Desa Wisata Ponggok.

Desa Ponggok sebagai desa wisata memiliki beberapa objek wisata unggul yaitu Umbul Sigedang, Umbul Kajen, Umbul Ponggok, Umbul Kapilaler, serta Umbul Cokro. Pada setiap umbul masing-masing umbul memiliki pemandangan alam yang indah, air yang jernih, suasana desa yang asri serta daya tarik yang berbeda-beda disetiap umbul tersebut maka sangat sesuai jika Desa Ponggok ini dikembangkan menjadi sebuah desa wisata. Dari ke-5 umbul ini yang paling menonjol adalah Umbul Ponggok.

Pengembangan kawasan wisata ini dapat memberikan kontribusi pada pendapatan asli daerah, padahal pada tahun 2001 daerah ini pernah dijuluki desa termiskin di Indonesia. Kawasan wisata ini dapat membuka peluang usaha dan kesempatan kerja yang kreatif yang sekaligus dapat berfungsi menjaga dan melestarikan kekayaan alam dan hayati.

Dari penjelasan diatas dapat diketahui bahwa Pengelolaan objek Desa Wisata Umbul Ponggok ini berpengaruh dalam kehidupan masyarakat setempat dengan melestarikan kekayaan alam dan hayati. Maka dari itu peneliti ingin meneliti " Pengaruh Status Desa Wisata Terhadap Kehidupan Masyarakat Desa Ponggok".

\section{METODE}

Dalam penelitian ini, penulis menggunakan metode penelitian analisis deskriptif dengan pendekatan kualitatif. Fenomena itu bisa berupa bentuk, aktivitas, karakteristik, perubahan, hubungan, kesamaan, dan perbedaan antara fenomena yang satu dengan fenomena lain. Dimana penulis menggambarkan dan memaparkan kehidupan ekonomi, sosial, dan budaya masyarakat Desa Ponggok dari data-data yang didapat melalui studi kepustakaan dan kuesioner. 


\section{Lokasi Penelitian}

Adapun penelitian ini dilakukan di Politeknik Sahid Jakarta,Pondok Cabe, Banten mengunakan media telekomunikasi, menyebarkan form koesioner secara online kepada pihak Desa Ponggok, pada hari Senin, 11 Mei 2020.

Penelitian ini membahas tentang Dampak Budaya, Ekonomi, dan Sosial terhadap Pengaruh Status Desa Wisata Kehidupan Masyarakat Desa Ponggok.

\section{DATA PENELITIAN}

Populasi penelitian ini adalah masyarakat Desa Ponggok 2036 orang. Sementara itu sampel penelitian ini adalah sebanyak 38 orang. Berdasarkan metode Purposive Sampling. Berikut hasil persentase dari data responden.

\section{Gambar 3}

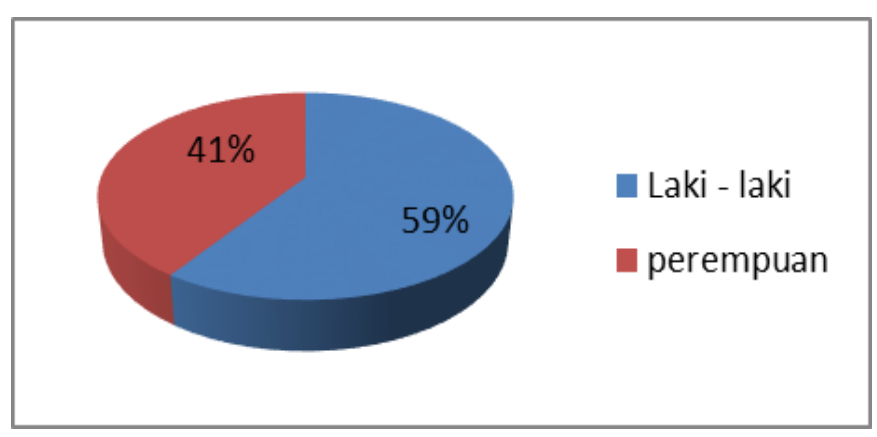

Berdasarkan sajian data chart diatas, dapat diartikan dalam kalkulasi pengisian kuesioner, responden yang mendominasi adalah jenis kelamin laki- laki yaitu memiliki presentase sebesar $59,5 \%$ dari pada total responden 38 orang dengan jumlah 23 orang, sementara responden dengan jenis kelamin perempuan mempunyai presentase sebesar 40,5\% dengan jumlah 15 orang. Dalam penyebaran koesioner ke media sosial seperti Instagram dan Facebook di bantu oleh BumDes, peneliti lebih banyak menemukan masyarakat Desa Ponggok berjenis kelamin laki- laki yang lebih aktif dalam media sosial dari pada jenis kelamin perempuan.

\section{HASIL DAN PEMBAHASAN}

Berdasarkan hasil penelitian dan pembahasan yang telah dilakukan, maka didapatkan hasil mengenai dampak pengaruh status desa wisata terhadap kehidupan masyarakat Desa Ponggok, yaitu dampak sosial yang dirasakan masyarakat Desa Ponggok setelah ditetapkannya sebagai desa wisata yaitu karna banyaknya wisatawan yang datang membuat masyarakat desa dapat berinteraksi dengan para pengunjung, kehidupan masyarakat desa yang lebih modern karna banyak masyarakat yang meninggalkan pekerjaan awal sebagai petani menjadi pekerja jasa wisata membuat pendapatan mengalami peningkatan, tingkat pendidikan yang semakin baik, dan tingkat kesejahteraan masyarakat desa pun mengalami peningkatan. Selain dampak positif ada pula dampak negatif yang di timbulkan diantaranya terjadi pencemaran lingkungan karna banyaknya wisatawan yang datang yang membuang sampah sembarangan.

Sementara itu untuk dampak perekonomian sangat dirasakan desa wisata karena mengalami banyak perubahan. Objek wisata ini membantu masyarakat meningkatkan keterampilan, kreatifitas dalam hal membuka serta mengelola usaha yang telah mereka bangun. Mulai dari di tetapkannya biaya masuk objek wisata sebesar Rp 15.000,00 yang sebelumnya tidak dikenakan tarif masuk objek wisata tersebut, penyewaan alat- alat snorkling, dan pemotretan under water. Untuk penyewaan alat- alat snorkling seperti kaki katak dikenakan biaya Rp. 7000,- , pelampung jaket Rp.7000,-, dan ban Rp. 5000,-. Pengelola juga menawarkan paket alat snorkling dengan harga Rp. 13.000,-. Pada Pemotretan bawah air, dikenakan biaya Rp. 100.000,- perjam, untuk setengah jam dipasok harga Rp. 60.000,-. Pengunjung Desa Wisata Umbul Ponggok 
kebanyakan hanya menyewa tas waterproof untuk handphone, dan pengelola juga menyediakan jasa peminjaman kamera yang hanya bisa di pakai dua kali pemotretan. Keluarga di Desa Ponggok 76\% sudah melakukan investasi ke BUMDes Tirta Mandiri, nilai investasi yang diberikan sekitar Rp. 5 juta per keluarga. Setiap satu keluarga menerima hasil sekitar Rp. 400.000,- hingga Rp. $500.000,-$ perbulan. Pendapatan per kapita warga di Ponggok saat ini berkisar Rp 1.500.000,hingga $2.000 .000,-$.

Sedangkan untuk kehidupan budaya masyarakat di Desa Ponggok setelah di tetapkan sebagai desa wisata mengalami beberapa perubahan. Sebelum di kelola menjadi desa wisata, masyarakat Desa Ponggok sebagian besar bermata pencaharian sebagai petani, setelah menyandang status sebagai desa wisata yang di kelola bumDes Tirta Mandiri masyarakat banyak yang beralih profesi menjadi penyedia jasa wisata maupun pedagang. Banyaknya wisatawan asing yang berkunjung menjadikan masyarakat bisa berbahasa asing, selain itu juga memunculkan budaya baru karna adanya percampuran budaya yang terjadi antara budaya lokal dan budaya yang dibawa wisatawan, dan yang paling utama adalah masyarakat desa dapat memperkenalkan budaya lokal kepada para wisatawan sehingga budaya lokal bisa dikenal masyarakat banyak diluar daerah.

\section{SIMPULAN}

Setelah ditetapkan sebagai Desa Wisata, kehidupan masyarakat desa banyak mengalami perubahan, baik itu dari segi sosial, ekonomi dan budaya. Hal ini terjadi karena masyarakat desa yang bekerja sama dengan BUMDes mampu mengelola desa sehingga Desa Ponggok berhasil berganti status menjadi Desa Wisata mandiri yang dapat menghasilkan pendapatan hingga milyaran rupiah per tahun. Hal ini membuat masyarakat menjadi lebih maju dan sejahtera.

\section{DAFTAR PUSTAKA}

Aditya Putra, Dwi. 2018 "Data BPS : Indonesia Memiliki 1.734 Desa Wisata" https://www.merdeka.com/uang/data-bps-indonesia-miliki-1734-desa-wisata.html Diakses tanggal 20 Maret 2020

Projo, Wahyu Adityo. 2019. "Wisata Umbul Ponggok Sigedang" https://travel.kompas.com/read/2019/07/08/200700227/panduan-wisata-ke-umbul-sigedang-

sumber-mata-air-menyegarkan-di-klaten?page=all Diakses tanggal 20 Maret 2020

Review Tempat Wisata Umbul Ponggok https://www.tripadvisor.co.id/Attraction_Reviewg4355635-d7296241-Reviews-Umbul_Ponggok-Klaten_Central_Java_Java.html Diakses tanggal 29 Mei 2020

Badan Statistika Provinsi Jawa Tengah. 2018. "Jumlah Wisatawan Mancanegara dan Domestik di Provinsi Jawa Tengah, 2011-2018 “ https://jateng.bps.go.id/statictable/2017/10/30/1618/jumlahwisatawan-mancanegara-dan-domestik-di-provinsi-jawa-tengah-2011-2018.html Diakses tanggal 14 Maret 2020

Humas Jateng, 2019 "Tak Hanya Kaya, Ponggok Kini Juga Jadi Desa Pintar" https://humas.jatengprov.go.id/detail_berita_gubernur?id=2040. Diakses 18 April 2020

Kementrian Kebudayaan dan Pariwisata. 2018. "Pendapatan Devisa Indonesia dari Sektor Pariwisata Tahun 2009-2019" https://databoks.katadata.co.id/datapublish/2018/09/10/berapapendapatan-devisa-dari-sektor-pariwisata-indonesia Diakses tanggal 27 Maret 2020

Suryono, Haryono 2019. "Bumdes Tirta Mandiri Ponggok di Jawa Tengah yang makin trendi" https://gemari.id/gemari/2019/9/10/bumdes-tirta-mandiri-ponggok-di-jawa-tengah-yang-makintrendi Diakses tanggal 14 Maret 2020

Tempo.CO, 2017 "Ponggok Jadi Desa Wisata Terbaik, Ratusan Warganya Jadi Investor" https://nasional.tempo.co/read/876100/ponggok-jadi-desa-wisata-terbaik-ratusan-warganya-jadiinvestor. Diakses 16 Mei 2020

Website Desa Pintar Desa Wisata Ponggok. “ Bumdes Tirta Mandiri Mengerakan Sektor Perekonomian Desa Ponggok" http://ponggok.desapintar.co.id/potensi/detail/29-06-2018-bumdesatirta-mandiri-menggerakkan-sektor-perekonomian-desa-ponggok Diakses tanggal 29 Mei 2020 